\title{
FEDERALISM AND INVESTOR \\ PROTECTION: CONSTITUTIONAL \\ RESTRAINTS ON PREEMPTION OF \\ STATE REMEDIESFOR SECURITIES \\ FRAUD
}

\author{
MANNING GILBERT WARREN III*
}

I

\section{INTRODUCTION}

D uring the past five years we have experienced unprecedented success in our capital markets, marked by a record number of registered public offerings, a record amount of capital raised in the primary market for securities, and a record volume and appreciation in our nation's secondary markets for securities. ${ }^{1}$ For the first time, investors have invested more money in mutual funds than the amount on deposit in our commercial banks. ${ }^{2}$ These positive developments have occurred not in a laissez-faire system, but in a dual regulatory system providing both federal regulation and remedies and state regulation and remedies. ${ }^{3}$ This dual regulatory system and the accountability it demands from corporate management have provided the foundation for market confidence and market success. $^{4}$

The paradox is that this very success cyclically undermines the regulatory process. In a bull market so strong that even the dart throwers make money and corporate issuers who have never produced earnings are enjoying oversubscribed offerings of equity securities, no one wants to hear about fraud and

\footnotetext{
Copyright (C) 1997 by M anning W arren

This article is also available at http://www.law.duke.edu/journals/lcp.

* H. E dward Harter Chair of Corporate Law, Louis D. Brandeis School of Law, U niversity of Louisville.

The author gratefully acknowledges the insightful comments of his colleague, Professor E nid Trucios- $\mathrm{H}$ aynes, as well as the contribution of his research assistant, $\mathrm{R}$ odman Smythe, in the final preparation of this article.

1. See David Barboza, A nother Y ear of the Bull; D ow up 22\%, N.Y. TIMES, Jan. 1, 1998, at D 1 (reporting that, at year-end, the D ow J ones industrial average for the first time in its 100-year history had gained $20 \%$ or more for three consecutive years, an exemplification of the nation's "G oldilocks economy").

2. See Thomas S. M ulligan, I nvestors N eed to B e Wary of A buse, L evitt Says, L.A. TIM ES, F eb. 24,
} 1997, at D 2.

3. See generally M anning G ilbert W arren III, R eflections on D ual R egulation of Securities: A Case A gainst Preemption, 25 B.C. L. R EV . 495 (1984).

4. Seeid. at 497. 
abuse. $^{5}$ M oreover, as one commentator stated, "because bull markets tend to push all stock prices up, many investment frauds remain hidden" and "only when the bull turns tail do these swindles come to light." ${ }^{6}$ In a recent New York Times article, a journalist chronicled how above-average market returns were bringing in stock promoters with criminal records. ${ }^{7}$ Similarly, a Business Week cover story in December 1997 reported that organized crime had made shocking inroads into the small-capitalization securities market. ${ }^{8}$ Thus, regula- $^{-}$ tion breeds the success that breeds complacency that, in turn, breeds resistance to regulation.

In the past two years, this cycle has been fully exploited by corporate issuers and their various support groups, including the A merican E lectronics A ssociation, the N ational A ssociation of M anufacturers, the Securities Industry A ssociation $^{9}$ and the A merican Institute of Certified Public A ccountants. Their lobbying effort, generously supported by computer technology companies, overwhelmed opponents representing rank and file investors, including the A merican A ssociation of R etired Persons, Public Citizen, and the Consumer Federation of A merica. It now appears that the strategic plan of this high-tech lobby always has had three major objectives: (1) to erect insurmountable procedural barriers for plaintiffs in pursuing express and implied causes of action under the federal securities laws; (2) to preempt state regulatory agencies from enforcing pre-sale disclosure standards; and (3) to foreclose investors' private remedies under both state blue sky statutes and the common law. The first two objectives largely have been attained through passage of the Private Securities Litigation R eform A ct of 1995 ("R eform A ct") ${ }^{10}$ and the National Securities M arket Improvement A ct of 1996 ("NSMIA"). ${ }^{11}$ The third objective, the preemption of private remedies traditionally afforded by state law, is being re-

5. See J oseph A. G rundfest \& M ichael Perino, Securities L itigation Reform: The First Y ear's Experience (visited A pr. 5, 1998), available at <http://securities.stanford.edu/report>. Professors G rundfest $\&$ Perino found a 7-16\% decline in the total volume of securities litigation in 1996 and suggested that the "increasing stock market prices in 1996 may have depressed litigation activity." Id.

6. G retchen M orgenson, D on't B ea Victim, FORBES, J une 2, 1997, at 42.

7. See David Barboza, On the Shady Side of the Bull Market, N.Y. TIMES, M ay 10, 1997, at C 1; see also Leslie Eaton, Investment Fraud Is Soaring A long with the Bull Market, N.Y. TIMES, N ov. 30, 1997, at A 1.

8. See G ary W eiss, The M ob on Wall Street, Bus. W K., Dec. 16, 1996, at 92; see also D ean Starkman \& D eborah Lohse, Charges M ark Wider Probe of M ob, Wall Street, W A LL ST. J ., N ov. 26, 1997, at C1.

9. The position of the Securities I ndustry A ssociation in supporting preemption of state blue sky laws and the common law of fraud is particularly noteworthy. Formerly the Investment B ankers A ssociation, it opposed the development of state blue sky laws on the ground that simple fraud laws, which did not require registration, full disclosure, or administrative review, afforded adequate protection against securities fraud. See MICHAEL E. PARRISH, SECURITIESREGULATION AND THE NEW DEAL 8 (1970). When federal securities laws were first proposed, it withdrew its support, claiming that state blue sky laws had eliminated the need for national regulation. See id. at 20.

10. Pub. L. N o. 104-67, 109 Stat. 737 (codified in scattered sections of 15 U .S.C. (Supp. I 1995-96)) [hereinafter the R eform A ct].

11. Pub. L. N o. 104-290, 110 Stat. 3416 (codified in scattered sections of 15 U.S.C. (Supp. I 199596)) [hereinafter the N SMIA ]. 
lentlessly pursued in the form of proposed "uniform standards" legislation that would federalize private causes of action for securities fraud.

This article begins with a brief description and analysis of the two bills already enacted, the R eform A ct and NSMIA. It then discusses the proposed uniform standards legislation, as reflected in two bills recently introduced in the U.S. H ouse of R epresentatives ${ }^{12}$ and a third in the U.S. Senate. ${ }^{13}$ A fter analyzing the normative arguments for and against this legislation, the article turns to what I perceive to be present and developing constitutional limitations. Coincident to the current bull market and the so-called "securities reform movement," the Supreme Court has embarked on a case-by-case reinvigoration of federalism and the dual sovereignty of state and federal governments sometimes obscured but ever-present in the bedrock of the Constitution. In doing so, a majority of the Court, comprised of Chief J ustice R ehnquist and J ustices 0 'Connor, Scalia, Thomas, and Kennedy, have focused not on preemption under the Supremacy Clause, but rather on the limitations federalism imposes on congressional power under the Commerce Clause. I conclude that despite the weight of normative arguments against preemption of investor remedies, predominant federalism postulates foreclose the proposed intrusion into investors' tort remedies traditionally afforded by the states under centuries-old common law. Based upon my own "symmetrical analysis" of active and dormant Commerce Clause powers, I propose supplementation of the traditional "rational basis" scope of review of commerce power legislation with a "strict scrutiny" review where federal legislation, like the proposed uniform standards legislation, seeks to veto or significantly abrogate regulation in areas of traditional state concern.

II

StATUTORY “REFORM"

\section{A . The Private Securities Litigation R eform A ct}

The publicized justification for the R eform A ct was to protect honest businesses from frivolous class actions brought under the Securities and Exchange Commission's ("SE C") Rule 10b-5 by greedy plaintiffs' lawyers on behalf of professional plaintiffs. A Ithough some abuses had occurred in the years leading to enactment, there was only negligible evidence of any explosion in the use of the R ule 10b-5 class action remedy the new law sought to destroy. In fact, according to a widely circulated study by Professors J oseph G rundfest and $\mathrm{M} \mathrm{i-}$ chael Perino of Stanford U niversity Law School, ${ }^{14}$ the number of securities class

12. Securities Litigation Improvement A ct of 1997, H.R. 1653, 105th Cong; Securities Litigation U niform Standards A ct of 1997, H.R. 1689, 105th Cong.

13. Securities L itigation U niform Standards A ct of 1997, S. 1260, 105th Cong.

14. See G rundfest \& Perino, supra note 5. 
actions had remained constant during the previous five years, and, interestingly, has remained constant in the two years since its passage in $1995 .^{15}$

In contrast to its ostensible purposes, the R eform A ct imposed serious procedural obstacles for defrauded investors in both class actions and individual actions for securities fraud. The R eform A ct tinkered with the class action remedy by imposing job qualifications for class representatives and lead plaintiffs, ${ }^{16}$ and fee limitations on class attorneys. ${ }^{17}$ Instead of exercising legislative restraint, Congress proceeded not only to fix the perceived failures of the class action, but also to fix investor remedies in individual lawsuits. This "fixing" actually amounted to a "breaking" of remedies that had well-served investors and their marketplace for half a century. The R eform A ct heightened pleading standards for defrauded investors to dizzying heights, ${ }^{18}$ while at the same time imposing a discovery blackout once a motion to dismiss has been filed. ${ }^{19}$ A this stage of any civil proceeding, it must be remembered that the court must accept as true all allegations in the complaint, ${ }^{20}$ yet Congress has challenged securities fraud victims not only by building a higher wall but by forcing them to climb it in the dark.

The R eform A ct then created safe harbors for projections and other forward-looking statements ${ }^{21}$ - provisions so ill-conceived that they have been criticized by prominent commentators as creating a license to lie. ${ }^{22} \mathrm{~A}$ nd, if

15. See National E conomic R esearch A ssociates, Federal Shareholder Class A ction Filings Rise to Pre-R eform A ct L evels as State Filings Fall, (J uly 1997 report, on file with author) [hereinafter NER A 1997 Study].

16. See R eform A ct, Sec. 101(a), § 27(a)(2)(A), (a)(3)(B), 109 Stat. 737, 737-39 (codified at 15 U.S.C. § 77z-1 (Supp. I 1995-96)); id. Sec. 101(b), § 21D(a)(2)(A), (a)(3)(B), 109 Stat. 737, 743-45 (codified at 15 U.S.C. § 78u-4 (Supp. I 1995-96)).

17. See id. Sec. 101(a), § 27(a)(6), 109 Stat. 737, 740 (codified at 15 U S.C. § 77z-1(a)(6) (Supp. I 1995-96)); id. Sec. 101(b), § 21D(a)(6), 109 Stat. 737, 745 (codified at 15 U .S.C. § 78u-4(a)(6) (Supp. I 1995-96)).

18. Id. See id. Sec. 101(b), § 21D (b)(2), 109 Stat. 737, 747 (codified at 15 U.S.C. § 78u-4 (Supp. I 1995-96)); see also U NITED STA TES SE CURITIES AND EXCHANGE COMMISSION, OFFICE OF GENERAL

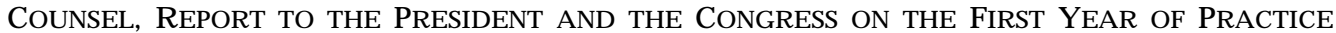
Under the Private Securities Litigation Reform Act of 199514 n.36 (A pr. 1997) (on file with author) [hereinafter REFORM A CT REPORT].

19. See R eform A ct, Sec. 101(a), § 27(b)(1), 109 Stat. 737, 741 (codified at 15 U.S.C. § 77z-1 (Supp. I 1995-96)); id. Sec. 101(b), § 21D (b)(3)(B), 109 Stat. 737, 747 (codified at 15 U.S.C. § 78u-4 (Supp. I 1995-96)).

20. In Conley v. Gibson, 355 U .S. 41 (1957), the Supreme Court held that a complaint should not be dismissed for failure to state a claim "unless it appears beyond doubt that the plaintiff can prove no set of facts in support of his claim which would entitle him to relief." Id. at 45-46. D espite the R eform A ct's heightened pleading requirements, a number of courts have been reluctant to permit these requirements to prejudice the plaintiff's claims. See, e.g., Rehm v. Eagle Finance Corp., 954 F. Supp. 1246 (N.D. III. 1997); see also Cooper v. Pickett, 122 F.3d 1168 (9th Cir. 1997), opinion amended on other grounds, 1998 WL 32678; Fischler v. A msouth B ancorporation, No. 96-1567-CIV-T-17A, 1996 U.S. Dist. LEXIS 17670 (M.D. Fla. N ov. 14, 1996).

21. See R eform A ct, Sec. 102(a), § 27A, 109 Stat. 737, 749 (codified at 15 U .S.C. § 77z-2 (Supp. I 1995-96)); id. Sec. 102(b), § $21 \mathrm{E}, 109$ Stat. 737, 753 (codified at 15 U .S.C. § 78u-5 (Supp. I 1995-96)).

22. For example, Professor J ohn C. Coffee, J r., has noted that the most striking feature of the R eform A ct's safe harbor "is the immunity it seems to give to a bald, knowing lie that is surrounded by 'meaningful cautionary statements.'" J ohn C. Coffee, J r., The F uture of the Private Securities L itigation R eform A ct: Or, Why the F at L ady H as N ot Y et Sung, 51 B U S. L A W. 975, 989 (1996). 
hope springs eternal and we assume the fraud victim can clear these hurdles and ultimately secure a verdict, the cheated investor will find that the joint and several liability traditionally afforded defendants has been replaced with a highly complex system of proportionate liability. ${ }^{23}$ Under this particular "reform," defendants found to have been primary violators of the securities laws are assigned only proportionate liability if their proven intent to deceive investors was based on reckless misconduct. ${ }^{24}$ O riginally, the high-tech lobby had insisted that "recklessness" be eliminated altogether as conduct satisfying R ule 10b-5's scienter requirement, ${ }^{25}$ but, at least for the time being, was satisfied with proportionate liability coupled with new pleading standards requiring particularity in averring the required state of mind. ${ }^{26}$

The passage of the R eform A ct seems to have worked little change in the number of securities class actions filed by investors. R oughly the same number of actions has been filed annually in the past two years as was filed annually during the three-year period preceding enactment. ${ }^{27}$ The $\mathrm{G}$ rundfest and Perino study, however, highlighted what the authors termed the "substitution effect," claiming that the R eform A ct caused a significant shift of activity from federal to state courts. ${ }^{28}$ A ccording to the study, approximately twenty-six percent of securities class action claims during the year following enactment were state court proceedings without parallel federal claims filed, and that at least twentyeight percent of federal class action cases had pending parallel state actions. ${ }^{29}$ H owever, further study through the first five months of 1997 belied the G rundfest-Perino report of a "boom" in state class action securities actions. National E conomic R esearch A ssociates, Inc. ("NERA") found the 1996 trend to have been transient. ${ }^{30}$ D uring the first four months of 1997, only nineteen cases were filed in state court, representing a significant slowdown in state court filings. ${ }^{31}$ Projections for 1997 indicated that only fifty-seven cases would be filed in state

23. See R eform A ct, Sec. 201(a), § 21D (g), 109 Stat. 737, 758 (codified at 15 U .S.C. § 78u-4 (Supp. ( 1995-96)).

24. Seeid.

25. Every federal circuit has held that recklessness satisfies the scienter requirement for primary violations of Rule $10 \mathrm{~b}-5$, but the Supreme Court has repeatedly reserved the question. See M anning Gilbert Warren III, The Primary Liability of Securities Lawyers, 50 S.M.U. L. REV. 383, 385 n.14 (1996).

26. The conference report accompanying the R eform A ct noted that the bill was not intended to change "the state of mind requirements of existing law." H.R. CONF. REP. N o. 104-369, at 38 (1995), reprinted in 1995 U S.C.C.A.N. 730, 737. For a useful discussion of the Reform A ct's inconsistent treatment of the "recklessness" issue, see D ennis T. R ice, A Practitioner's V iew of Private Securities Litigation Reform A ct of 1995, 31 U .S.F. L. REV. 283, 287-88 (1997).

27. See SE C Finds N umber of Class A ctions Rose in 1997 to Pre-R eform L aw L evels, 30 Sec. R eg. \& L. Rep. (BNA) 275 (Feb. 20, 1998). A ccording to SE C data, 175 and 105 companies were sued under the R eform A ct in 1997 and 1996, respectively, compared to 158 companies in 1995, 221 companies in 1994, and 153 companies in 1993. See id.

28. G rundfest \& Perino, supra note 5.

29. Seeid.

30. See NERA 1997 Study, supra note 15, at 1.

31. Seeid. at 2. 
court and 187 in federal court, ${ }^{32}$ figures that correlate closely with the number of cases filed annually during the five years prior to passage of the R eform A ct. ${ }^{33}$ Clearly, litigation has not boomed, as G rundfest and Perino conceded in Senate testimony last summer: "A nalysis of litigation activity through J une 30, 1997, reveals that the overall number of companies sued in securities class actions appears to be roughly equivalent to the number sued prior to the R eform A ct." ${ }^{34}$

While acknowledging the decline in state court filings, Grundfest and Perino nevertheless have clung to their "substitution effect" theory, reporting that ninety-two of 238 post-R eform A ct class action cases involved "at least some state component." ${ }^{35}$ This appears to be a case of a theory in search of its own evidence, for in the same testimony, the authors urged Congress to adopt uniform standards legislation, which would amend the savings clauses in the federal securities statutes to preempt investors' state securities fraud remedies. ${ }^{36}$ B oth the House and Senate versions of the proposed legislation would preempt fraud, misrepresentation, and other remedies traditionally provided investors under state law, whether asserted in state courts, federal courts, or, arguably, in arbitration proceedings. Moreover, former SE C Commissioner Steven Wallman has stated that R eform A ct proponents had planned from day one to begin by restricting federal remedies, and subsequently to preempt the corollary remedies historically provided by the states. In a recent interview, Wallman stated that these proponents believed that to argue for passage of the R eform A ct and "to advocate for the preemption of the states at the same time... would just be too difficult," adding that he believed "there was a real choice made by a lot of people working on" the R eform A ct to postpone preemption legislation to a later date. ${ }^{37}$

The legislative strike at the regulatory domain of state securities agencies would not be postponed for long. The second objective of the high-tech lobby's strategic plan was achieved in less than a year after passage of the R eform A ct. Congress enacted sweeping legislation that preempted state blue sky laws administered by state securities commissions for decades before Congress supplemented the states' regulatory systems by enacting federal securities legislation. ${ }^{38}$

32. See id. at 1-2.

33. See id. at 1.

34. J oseph A. G rundfest $\&$ M ichael Perino, Ten Things We Know and Ten Things We D on't K now A bout the Private Securities L itigation R eform A ct of 1995, at 5 (written testimony before the Senate Subcommittee on B anking, Housing, and U rban A ffairs, U nited States Senate, July 24,1997) (on file with author).

35. Id. at 6 .

36. See id. at 22.

37. R achel W itmer, SE C Commissioner Wallman Sees N eed for U niform Standards L aw, 29 Sec. Reg \& L. Rep. (B N A ) 1259 (Sept. 12, 1997).

38. See S. ReP. No. 47, at 2 (1933), reprinted in J.S. ElLenBerger \& ELLen P. MAhAR, 2

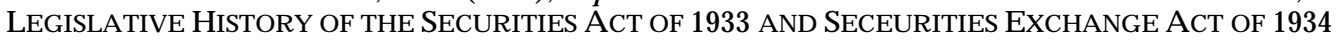
(1973). 


\section{B. The N ational Securities M arket I mprovement A ct}

Congress passed the NSMIA during the 1996 presidential election, after hearings that were described even by proponents of the statute as biased and one-sided. In contrast to the policies underlying the savings clauses in the federal securities laws, Congress has acted to preempt a substantial portion of state securities laws enacted by state legislatures and administered by state regulatory agencies since shortly after the turn of the century. In its zeal to court the high-tech lobby, Congress seemed to have forgotten that the federal securities laws were enacted to supplement state securities laws based on enforcement dilemmas occasioned by the jurisdictional limitations on the states' police powers, or, as J ustice William D ouglas pointed out in Travelers $\mathrm{H}$ ealth A ssociation v. Virginia, "to fill a gap." ${ }^{39}$ N ow, more than sixty years later, Congress has created its own gaps in the securities laws of the states and in the entire investor protection regime.

In the NSMIA, Congress has stretched its preemptive power under the Commerce Clause beyond constitutional limits in order to dictate its own limits on the states in defining their respective regulatory spheres. A mong other things, it has unilaterally "withdrawn" the preexisting power of the states to require pre-sale disclosures by issuers and to conduct pre-sale disclosure review, merit review, or any other kind of fairness review in connection with most public and private offerings of securities conducted within their respective jurisdictions. ${ }^{40}$ The federal statute orders the states to impose no limits or conditions on any "covered security" ${ }^{41}$ and has foreclosed the revenue raising function traditionally associated with state permitting requirements. ${ }^{42}$

The newly coined term "covered security" has to be one of the grandest misnomers financial legislation has ever seen. "Covered" refers not only to securities subject to the federal pre-sale disclosure regime but also to a comprehensive array of securities and securities transactions exempt from the federal regime and hence not "covered" at all at the federal level and, from the N SM I A forward, not "covered" by the states either. ${ }^{43}$ The term "covered security" encompasses virtually all public and private offerings of securities issued by companies whose securities are traded on the New Y ork ("NYSE") or A merican Stock Exchanges ("A MEX") or on the NA SD A Q National Market System and all securities issued by mutual funds. ${ }^{44}$ The term also includes all

39. Travelers H ealth A ss'n v. V irginia, 339 U .S. 643, 653 (1950) (D ouglas, J ., concurring).

40. See N SM I A Sec. 102(a), § 18(a), 110 Stat. 3416, 3417 (codified at 15 U .S.C.A. § 77r (1997)).

41. See id. Sec. 102(a), § 18(a)(2)(3), 110 Stat. 3416, 3417-18 (codified at 15 U .S.C. § 77r (Supp. I 1995-96)).

42. See id. Sec. 102(a), § 18(c)(2)(D), 110 Stat. 3416, 3420 (codified at 15 U.S.C. § 77r (Supp. I 1995-96)).

43. See id. Sec. 102(a), § 18(b)(1-4), 110 Stat. 3416, 3418-19 (codified at 15 U.S.C. § 77r (Supp. I 1995-96)).

44. See id. Sec. 102(a), § 18(b)(1)(A), 110 Stat. 3416, 3418 (codified at 15 U.S.C. § 77r (Supp. I 1995-96)). 
securities sold to so-called "qualified purchasers," 45 as defined from time to time by the SEC, and most of the securities and securities transactions exempt from federal registration under sections $3(a)^{46}$ and $4^{47}$ of the Securities A ct of 1933 ("1933 A ct"), including all private offerings exempt under R ule 506 of the SE C's R egulation D. ${ }^{48}$ Congress apparently had forgotten that it had enacted these exemptions from registration at the federal level based on its own recognition at the time of the $1933 \mathrm{~A}$ ct's passage that sufficient pre-sale regulatory protection already was being provided at the state level. Moreover, it apparently had forgotten that substantial congressional opposition to the $1933 \mathrm{~A} \mathrm{ct}$ 's disclosure-only regime had been overcome by preserving state regimes that provided merit review and localized scrutiny of securities offerings and their issuers. ${ }^{49}$ In its haste to enact the N SM IA, Congress ignored much of the legislative history of the federal securities laws, and, consequently, the underlying policies that established the dual regulatory system in the first place.

$\mathrm{H}$ aving gutted the states' pre-sale disclosure and merit review regulation, Congress did not undertake to abolish state securities commissions or their authority to investigate and enforce their own differing laws of fraud and deceit. In other words, Congress determined that the states could prosecute issuers after the sale of those very securities Congress would not allow them to review before these securities were sold. In preserving the states' post-sale antifraud enforcement authority, Congress clearly demonstrated the irrationality of the NSMIA's ostensible policy promoting national uniformity. A fter all, differing enforcement decisions under the states' disparate anti-fraud laws could produce significant inconsistencies between federal and state disclosure standards, and, hence, do not serve the goal of regulatory uniformity the NSM IA ostensibly sought to achieve.

In addition, Congress decided to ameliorate state concerns that because of eliminated registration fees, new financial resources would have to be found to fund the states' newly limited role as "cops on the beat." To diffuse opposition from state regulatory agencies, Congress agreed to preserve the fees payable to the states for registration of the very securities offerings that states were no longer allowed to regulate. In doing so, Congress disregarded the essential postulates of federalism by expressly providing in the statute that for three years after the NSMIA's enactment, issuers would have to buy the benefits of preemption by paying filing or registration fees to those states that still required them. ${ }^{50}$ The statute provides that should these nonregistrants refuse to pay the fees, the states can continue to require those companies to register their cov96)).

45. See id. Sec. 102(a), § 18(b)(3), 110 Stat. 3416, 3418 (codified at 15 U .S.C. § 77r (Supp. I 1995-

46. 15 U .S.C. § 77c(a) (1994).

47. Id. $\S 77 d$.

48. See 17 C.F.R. § 230.506 (1997).

49. See Warren, supra note 3 , at 518-19.

50. See NSM IA Sec. 307(a), 110 Stat. 3416, 3440 (codified at 15 U.S.C. § 80b-3a note (Supp. I 1995-96)). 
ered securities. $^{51}$ A ccordingly, until 0 ctober 11, 1999, Congress has authorized a truly unique offering of preemptive rights. By pinning a price tag on preemption, Congress has again contributed to the non-uniformity it purportedly sought to overcome.

In other parts of the NSM IA, Congress significantly limits the authority of the states to regulate broker-dealers and investment advisers. With respect to broker-dealer regulation, Congress has preempted state laws that impose capital, margin, reporting, and record-keeping requirements inconsistent with federal law. ${ }^{52}$ With respect to investment advisers, Congress has developed a "dividing the pie" approach, allocating regulatory authority to the states for investment advisers with less than \$25 million under management and to the SE C for all others. ${ }^{53}$ In sum, C ongress, through the N SM IA, has usurped a huge portion of the states' police powers, eliminating most of the states' registration authority and significantly reducing the states' role in regulating broker-dealers and investment advisers. A II of this begs the questions how? and why?, especially during a period that delivered more capital formation and greater trading volume than at any other time in our history. Shortly after the NSM IA 's passage, SE C Chairman A uthur L evitt, while addressing the securities administrators of the fifty states, prophesied "that passage of this bill will end the national debate on preemption for many years to come." ${ }^{54}$ Chairman L evitt's projection regarding the prospects for preemption soon proved materially erroneous. Indeed, put in their best light, Chairman L evitt's falsely prophetic remarks were reminiscent of the high-sounding political rhetoric, continuously expressed since the beginning of the Reagan Administration, that federal regulatory power should be decentralized and reduced through a corresponding expansion of state regulatory power. ${ }^{55}$

\section{The Securities L itigation U niform Standards L egislation}

In less than one year before the 1996 elections, Congress had been persuaded both to limit drastically the private federal remedies historically available to investors to redress corporate misconduct and to obliterate for the most part the role of state securities administrators in the securities offering process. The high-tech lobby, fresh off these successes (and also having rebuffed an at-

51. See id. Sec. 307(c), 110 Stat. 3416, 3440 (codified at 15 U .S.C. § 80b-3a note (Supp. I 1995-96)). 52. See id. Sec. 103(a), § 78o(h)(1), 110 Stat. 3416, 3420-21 (codified at 15 U .S.C. § 770 (Supp. I 1995-96)). 96)).

53. See id. Sec. 303(a), § 203A, 110 Stat. 3416, 3437 (codified at 15 U .S.C. § 80b-3a (Supp. I 1995-

54. A rthur Levitt, The SEC and NA SA A : Working Together to Protect I nvestors, R emarks at A nnual Fall Conference of the N orth A merican Securities A dministrators A ssociation, Salt Lake City, U tah (Sept. 9, 1996) (transcript on file with author). Curiously, Chairman L evitt subsequently has endorsed the G ramm bill, noting that "dual standards in state and federal court are wrong." SE C Throws Weight B ehind Reform Bill; L evitt Praised at Renomination Hearing, 30 Sec. Reg. \& L. Rep. (BNA) 477 (M ar. 27, 1998).

55. See generally Final Report of SEC Transition Team, [J an.-J une] Sec. Reg. \& L. R ep. (BNA) No. 587, at K-1 (J an. 21, 1981). 
tempt by the plaintiffs' bar to strengthen investor remedies under California $\left(a^{56}\right)$ moved forward to the final phase of its strategic plan. If expansion of state remedies could be defeated, why not push for their elimination altogether? Moreover, if a willing Congress could be persuaded to take the teeth out of R ule 10b-5 and other express and implied remedies under the federal securities laws, why not convince it, in the name of uniformity, to protect its reforms by preempting the common law of fraud and closing the investors' doors to state courthouses? R eorganizing itself as the U niform Standards Coalition, ${ }^{57}$ the high-tech lobby once again has come to Washington. N ot surprisingly, the Coalition already has secured broad-based bipartisan support for legislation that would preempt state securities fraud laws. A rmed with the GrundfestPerino study and its updates, the Coalition has advanced the "substitution effect" theory, arguing that investors, unable to comply with more stringent pleading requirements under the $\mathrm{R}$ eform $\mathrm{A} \mathrm{ct}$, were shifting their claims to state courts and asserting causes of action under state law. ${ }^{58}$ A ccording to the Coalition, this shift undermines the R eform A ct's purposes to end abusive securities litigation, sabotages the R eform A ct's safe harbor for disclosure of forwardlooking information, circumvents the R eform A ct's discovery stays, facilitates frivolous lawsuits, erodes the efficiency of national markets, and imposes excessive legal costs on corporate issuers. ${ }^{59}$ A nd, in a significant affront to federalism's dual sovereignty postulate, the Coalition has stated, "protection against fraud and other investors' rights should not vary because of where people live." ${ }^{60}$

A Ithough the statistical evidence of the shift from federal to state court is far from convincing at this stage, such a shift would make strategic sense given the R eform A ct's restrictions on federal remedies. Indeed, one court, in refusing to stay a state securities fraud class action parallel to a federal one on related claims, has stated that a dual-track litigation strategy is not only permissible but that the R eform A ct "effectively compels" parallel filings. ${ }^{61}$ Certainly a parallel or stand-alone state securities fraud action would facilitate the investors' discovery of facts necessary to sustain the case during the motions phase

56. See Proposition 211, 1996 Cal. L egis. Serv. Prop. 211 (West).

57. The U niform Standards Coalition was formed by the Securities Industry A ssociation, A merican Electronics A ssociation, A merican Institute of Certified Public A ccountants, and the National Venture Capital A ssociation. A ccording to their own materials promulgated by the National A ssociation of Securities and Commercial L aw A ttorneys, it was formed in response to the unprecedented rise in securities class actions in state courts against high-growth companies. See BACKGROUND MATERIA LS: PREEMPTION OF STA TE SECURITIES LA WS IN THE 105TH CONGRESS (on file with author).

58. See National A ssociation of Securities and Commercial Law A ttorneys, M eritless Securities L awsuits: The A buse Some Lawyers Can't Live Without, in UNIFORM STANDARDS COALITION BACKGROUND MATERIALS, PRESSKIT, at 1, 3, 4 (May 6, 1997) (on file with author).

59. See National A ssociation of Securities and Commercial Law A ttorneys, Uniform Standards, Finish the J ob: E nd A busive Securities Litigation, in U NIFORM STA NDARDS COALITION BACK GR OUND MATERIALS, PRESS KIT, at 2 (M ay 6, 1997) (on file with author).

60. National A ssociation of Securities and Commercial L aw A ttorneys, supra note 58, at 5.

61. See Calif. Court Finds No Error in Refusal to Stay State Litigation, $29 \mathrm{Sec}$. Reg. \& L. Rep. (BNA) 1214 (A ug. 29, 1997) (discussing Oak Tech. v. Superior Court, N o. H O 16141 (Calif. Ct. A pp., A ug. 14, 1997)). 
of their case and thus permit a jury determination of the defendant's liability. Obviously, if Congress had determined to go one step further and deny defrauded investors any private remedy at the federal level, we would be rid of parallel actions and defrauded investors would have no choice but to pursue state law remedies in state courts. A ssuming arguendo a shift to state courts, no study to date offers objective evidence that securities fraud actions filed either in state courts or that state causes of action under state law tend to be abusive, frivolous, or destructive of market efficiency. No evidence indicates that pleading requirements or discovery rights provided by state courts discriminate against corporate defendants or have been abused by investor plaintiffs. Moreover, it is far too early to determine whether these lawsuits have had any impact on the R eform A ct's safe harbor for forward-looking information. Indeed, SE C Chairman L evitt has advised both President Clinton and Congress that "it is too early to assess with confidence many important effects of the R eform A ct and ... premature to propose legislative changes." ${ }^{62}$ Not surprisingly, Commissioner Wallman disagreed, refusing to accept the "fragmentation of our national system of securities litigation." ${ }^{63}$ Of course, under federalism's dual regulatory structure we have never had a "national system of securities litigation."

In response to the Coalition's calls for legislation that would preempt investors' state law remedies, a number of consumer and government groups have voiced strong opposition. The Consumer Federation of A merica, the A merican A ssociation of $\mathrm{R}$ etired Persons, and the Consumers $U$ nion have stated collectively that Congress should not act until "seeing real, conclusive evidence of how the litigation reform act has affected the ability of defrauded investors to recover their losses" and, without that evidence, Congress should not "support legislative initiatives that would extend this untested experiment to lawsuits brought under state laws." ${ }^{64}$ The Gray Panthers, expressing their opposition more bluntly, have stated that if the R eform A ct "turns out not to provide adequate protections against fraud-as we fear-state remedies will be all that older people have left if they are to recover what is stolen from them." ${ }^{15}$ Taking a different tack, various government groups, including the National L eague of Cities, the U.S. C onference of M ayors, and the G overnment Finance O fficers A ssociation, have stated that "states must be able to protect state and

62. L etter from A rthur L evitt, Chairman of the U nited States Securities and Exchange Commmission, to President William J. Clinton (A pr. 15, 1997) (on file with author); see also REFORM ACT REPORT, supra note 18.

63. Statement of A dditional Views of Commissioner W allman R egarding The R eport of the First $Y$ ear of Practice under the Private Securities Litigation R eform A ct of 1995 (A pr. 11, 1997) (on file with author); see also REFORM A CT REPORT, supra note 18.

64. General Information Letter by Barbara R oper of the Consumer Federation of A merica and B etsy D otson of the G overnment Finance O fficers A ssociation (quoting L etter to President W illiam J . Clinton from A merican A ssociation of R etired Persons, Citizens A ction, Consumer Federation of A merica, Consumers U nion, Public Citizen's Congress W atch, U .S. Public Interest R esearch Group) (A ug. 13, 1997) (on file with author).

65. Letter from Tim Fuller, Executive D irector, Gray Panthers, to President W illiam J. Clinton (Sept. 11, 1997) (on file with author). 
local government funds and their taxpayers regardless of (or because of) the obstacles present in federal law," that "preemption ... would be contrary to the principles of federalism," and that "without meaningful access to state courts and reasonable remedies, public funds will be at greater risk than ever." ${ }^{66}$

Neither the strong opposition from consumer and government groups nor the note of caution sounded by the SE C seems to have slowed the Coalition's objective. In the spring of 1997, before a single post-R eform A ct case had made its way to a jury, the first of the three state remedy preemption bills, H.R . 1653, ${ }^{67}$ was introduced by Representative Tom Campbell of California. This bill would amend the savings clauses of both the $1933 \mathrm{~A}$ ct and the Securities Exchange $A$ ct of 1934 by providing that no private civil action alleging a misrepresentation or omission or use of a manipulative or deceptive device in connection with the purchase or sale of any "covered security" ${ }^{68}$ may be initiated or maintained in any state court, or under state law as a pendent claim to an action under federal law. ${ }^{69}$ In addition, the bill would amend the $1933 \mathrm{~A}$ ct to substitute exclusive federal jurisdiction for the longstanding concurrent jurisdiction of state and federal courts. ${ }^{70}$ The Campbell bill would not only deny defrauded investors in nationally traded securities all access to state courts, but would forbid them from asserting as pendent claims in a federal forum any rights arising under state securities acts or under the laws of fraud, deceit, negligent and intentional misrepresentation and, conceivably, breach of fiduciary duty and conversion. M oreover, the preemption of these claims would eliminate any opportunity for the recovery of punitive damages and attorney fees available only under state law. Significantly, this bill does not distinguish class actions from individual actions, and, accordingly, precludes both. A nd the limitation to "covered securities" under Section 18(b)(1) of the $1933 \mathrm{~A} \mathrm{ct}^{71}$ added by the NSMIA, effectively immunizes those issuers with securities traded on the NY SE , A MEX, or NA SD A Q 's N ational M arket System. The issuers remaining as potential defendants subject to investor claims under state law are presumably only those companies that publicly offer securities that are traded in the small capitalization markets or are not traded at all.

A ccordingly, it appears that smaller, less capitalized businesses will remain targeted under state law while larger, better capitalized companies will be granted immunity from the statutory and common law of the states. In other words, what Commissioner W allman described as our "national system of securities litigation" remains as fragmented as ever, but, it is fragmented in favor of

66. Letter from National L eague of Cities, National A ssociation of Counties, National A ssociation of County Treasurers and Finance Officers, M unicipal Treasurers' A ssociation, G overnment Finance Officers A ssociation, and U.S. Conference of Mayors to The Honorable A Ifonse D'A mato of the Committee on Banking, H ousing and U rban A ffairs (J uly 24, 1997) (on file with author).

67. H.R. 1653, 105th Cong. (1997).

68. Id. Sec. 2(a)(1), § 16(b)(1)(A), (f)(1)(A).

69. Seeid. Sec. 2(a)(1), § $16(b)(1)(B),(f)(1)(B)$.

70. Seeid. Sec. 2(a)(1), § 16(b), (f).

71. Seeid. Sec. 102(a)(1), § 16(b)(2), (f)(2). 
nationally traded companies who are placed in an especial class of companies against which state law claims may not be asserted and punitive damages may not be assessed. U nder this scenario, the smaller companies' regulatory burdens would be disproportionately higher with resulting disclosure obligations developing on separate tracks. A the same time, both types of issuers would remain equally subject to state governmental prosecution civilly and criminally under regulatory regimes that differ markedly from state to state. It is difficult to surmise how this bill would promote national uniformity or deter abusive or frivolous litigation. The intrusive means that Congress would employ thus bear less than a rational relationship to the goals it would seek to achieve.

The Campbell bill was quickly followed by another, H.R . 1689, ${ }^{72}$ introduced by R epresentatives R ick White of W ashington and A nna E shoo of California, with some ninety-five co-sponsors, including R epresentative Campbell. This bill calls for a curious redefinition of class action requirements. It would redefine class actions to include any single lawsuit or group of lawsuits filed or pending in the same court involving common questions of law or fact in which damages are sought on behalf of more than twenty-five persons, where one or more named parties seeking to recover damages on a representative basis, or where one or more of the parties did not personally authorize the lawsuit. ${ }^{73}$ Instead of eliminating concurrent jurisdiction generally under the $1933 \mathrm{Act}$, the bill would eliminate concurrent jurisdiction only as to class actions preempted by the bill. ${ }^{74}$ H owever, it broadly extends the term "covered security" to all securities of issuers that had "covered securities" of any kind outstanding at the time of the alleged misconduct, regardless of whether the fraud was in connection with the purchase or sale of those securities. ${ }^{75}$

The Senate bill, S. $1260{ }^{76}$ introduced on 0 ctober 7, 1997, by Senators Phil G ramm of Texas and Chris D odd of C onnecticut, is identical to its H ouse counterpart except for its use of the term "covered security," which would extend not to the issuer generally but to securities that are traded on one of the three designated marketplaces and to securities issued by mutual funds. ${ }^{77}$ Similar to the Campbell bill, both the White-E shoo and G ramm-D odd bills would create an especial class of companies immune from fraud claims based on state statutory and common law. This immunity likely would extend to a broad range of claims based on breach of fiduciary duty under the common law and breach of the duties of care and loyalty under state corporation codes. A fter all, a substantial portion of shareholder suits for breach of fiduciary duty, particularly in connection with proxy fights, tender offers, and mergers, include averments of material misrepresentations and omissions in connection with the purchase or sale of a security. In this context, the legislation could foreclose filing of share-

\footnotetext{
72. H.R. 1689, 105th Cong. (1997).

73. See id. Sec. 2(a)(1), § 16(d)(1)(A)-(C).

74. Seeid. Sec. 2(a)(2).

75. See id. Sec. 2(a)(1), § 16(d)(2).

76. S. 1260, 105th Cong. (1997).

77. Seeid. Sec. 2(a)(1), § 16(d)(2).
} 
holder derivative actions, a special form of class action which generally constitutes the sole remedy of shareholders for breach of duties owed by officers and directors to the corporations they serve. A ccording to one prominent observer, the White-E shoo and G ramm-D odd bills would preempt a whole body of state corporate law and the "uniformity of Delaware state law would be eroded," creating a "mess" inimicable to corporate A merica's interests. ${ }^{78}$

The uniform standards legislation would serve no purpose other than a substantial reduction of liability exposure for corporate misconduct by a favored group of companies. In exculpating these companies from state law claims, these bills would significantly frustrate the conduct monitoring function performed by the private bar in its representation of aggrieved investors. A II of these proposals would limit access to justice for investors defrauded by nationally traded companies or their leadership by forcing investors to use the procedurally and substantively restricted remedies provided at the federal level and denying those investors the statutory and common law remedies traditionally afforded by the states.

Obviously, the legislation will do little to promote the ostensible goal of uniformity. State administrative agencies and attorney generals would continue to prosecute, civilly and criminally, fraud-based misconduct in violation of state law disclosure standards. D efrauded investors would continue to assert state law disclosure standards in suits against companies whose securities are not traded in major marketplaces and differing federal law disclosure standards against those companies whose securities are traded in those marketplaces. A nd, under the White-E shoo and Gramm-Dodd bills, defrauded investors would assert differing state and federal disclosure standards in individual actions and federal disclosure standards in newly defined "class actions." M oreover, because of the likely intrusion into state corporate law that courts have long refused to federalize, ${ }^{79}$ the legislation could disrupt the established uniformity of state corporate laws that govern both publicly-held and closely-held corporations. ${ }^{80}$ Indeed, the proposed uniform standards legislation could create an unprecedented "mess" of conflicting disclosure standards and conflicting

78. R achel W ilmer, SE C, Private B ar A re Working to A ddress A lleged Flaw in Pending L egislation to Reform Securities L itigation, 13 BNA 'S CORP. COU NSE L W KLY . 8 (Feb. 4, 1998).

79. In Santa Fe Indus. v. Green, 430 U .S. 462 (1977), the Supreme Court expressed its reluctance "to federalize the substantial portion of the law of corporations that deals with transactions in securities, particularly where established state policies of corporate regulation would be overridden." Id. at 479. Indeed, the E nglish Crown's power over corporations devolved directly to the people, and, hence, to the states at the time of the revolution. See Trustees of D artmouth College v. W oodward, 17 U S. 518,651 (4 Wheat.) (1819). A s J ustice Powell stated more recently, "no principle of corporation law and practice is more firmly established than a [s]tate's authority to regulate domestic corporations." CTS Corp. v. D ynamics Corp. of A m., 481 U .S. 69, 89 (1987).

80. The Delaware G eneral Corporation L aw and the A merican B ar A ssociation's widely adopted R evised M odel B usiness Corporation A ct, as interpreted and applied by state courts, have established a body of comparable principles among the states that apply regardless of a given corporation's size or marketplace status. For a history of the evolution of modern general corporation statutes, see JAMES D. COXET AL., CORPORATIONS 29-37 (1997). 
remedies within and between the established complementary regimes of federal and state law developed for the protection of investors and their marketplace.

The proposed legislation has no rational basis, either in promoting nationwide uniform disclosure standards or in preventing abusive or frivolous litigation. No one has presented persuasive evidence that investors generally have behaved frivolously or abusively in asserting securities fraud claims against corporate issuers or that the assertion of claims and remedies traditionally afforded under state law has seriously frustrated congressional purposes. Instead, as SE C Commissioner Norman J ohnson has concluded, the controversy underlying the legislation "appears to be driven by anecdotes and ideology rather than hard facts." ${ }^{81}$ M oreover, it is doubtful that Congress has the requisite power to enact any of these three legislative proposals. Its proposed preemption of state remedies not only lacks a rational basis in promoting the goals sought to be achieved, but also lacks persuasive proof of substantial and commercial effects on interstate commerce. B efore preempting state law and state remedies, Congress must consider essential postulates of federalism that define the limits of its delegated commerce power and the residuum of power retained by the states.

A this juncture, it is difficult to predict the fate of the proposed uniform standards legislation. ${ }^{82}$ Clearly, each of the three versions introduced raises serious questions as to whether congressional power under the Commerce Clause is sufficiently extensive to divest securities investors of all protection under the statutory and common law of the states. Without that power, of course, Congress cannot preempt the states. A ssuming arguendo that the proposed or similar legislation is enacted, it is unlikely to survive constitutional challenge. The balance of this article focuses on the presumed challenge and the probability that the essential postulates of federalism pretermits congressional use of the commerce power to eliminate the powers of the states to provide nondiscriminatory remedies to investors.

III

Judicial Delineation of “A ctive" and Dormant Commerce Clause POWERS

\section{A . Constitutional Limits on Congressional Commerce Power}

The proposed uniform standards legislation involves the takeover of the people's centuries-old common law remedies, statutory remedies under blue sky laws that long preceded the federal securities statutes, and remedies for

81. Testimony of the U.S. Securities and Exchange Commission B efore the Subcommittee on Securities, Committee on B anking, Housing and U rban A ffairs, U.S. Senate 23 n.35 (Oct. 29, 1997) (on file with author).

82. Senator Gramm recently has predicted that his version of the legislation, S. 1260 , will pass the Senate and possibly the $\mathrm{H}$ ouse. See G ramm P redicts Passage of B ill to Federalize Securities Class Suits, 30 Sec. Reg. \& L. R ep. (BNA) 321 (Feb. 27, 1998). 
breach of fiduciary duty well established under state corporate law. This strike at the heart of state power presents a critical challenge to the constitutional federalism that arose from the people's ceding of certain power to the federal government while retaining the residuum for themselves and their respective states. If Congress can proceed freely at the behest of a heavily financed lobby to pare away the protections afforded by the common law, by our state judiciaries, and by our state legislatures, whatever is left of the federalist structure undergirding our Constitution comes close to collapse. A dmittedly, limits seemed to have been lost as $\mathrm{New}$ D eal legislation gradually overcame Commerce Clause restrictions evident in cases like $\mathrm{H}$ ammer v. D agenhart, ${ }^{83}$ a W orld War I decision in which the Supreme Court, recognizing that federalism required a narrow interpretation of congressional commerce power, held that the manufacture of goods was not commerce. ${ }^{84}$ By World War II, the Supreme Court had changed course and, in U nited States v. D arby, ${ }^{85}$ overruled $\mathrm{H}$ ammer. Then, in the 1950s and 1960s, the commerce power was further liberalized through judicial support of a well-meaning Congress in the valiant effort to protect the civil rights of our minorities. To assert the rights of the states became heresy and federalism became the refuge of racists. The great national struggles demanded by both the Depression and the civil rights movement tested the limits of core constitutional principles like federalism and the dual sovereignty it established. Unfortunately, Congress has grown accustomed to its postD epression powers and, with considerable judicial support, has come to believe that life itself is interstate commerce and that it can use commerce power to reshape or reconfigure the role of the states in any way it so desires.

H owever, despite decades of liberal interpretation by the Supreme Court, limits to that power do exist. It has been well established that for Congress to act legitimately under its enumerated Commerce Clause power, the subject matter Congress seeks to regulate must "substantially affect" interstate commerce. ${ }^{86}$ If no "substantial" and "commercial effect" is shown, Congress has no power to act and, accordingly, has no Supremacy Clause protection and no preemptive power over the states. In recent years, the Supreme Court, giving long overdue recognition to our federalist structure, has begun to reinvigorate the definitive limits of congressional power under the Commerce Clause.

The origins of the modern debate over the limitations imposed on congressional authority by the essential postulates of federalism may be traced in part to the Supreme Court's decision in National L eague of Cities V. U sery. ${ }^{87}$ In an

83. 247 U .S. 251 (1918).

84. See id. at 271-72. The Court held that Congress had no Commerce Clause power to enact child labor laws prohibiting transportation of child-made goods in interstate commerce. See id. at 276 . The Court feared that if it permitted such an intrusion into matters of local concern, "all freedom of commerce will be at an end, and the power of the States over local matters may be eliminated, and thus our system of government be practically destroyed." Id. at 276.

85. 312 U .S. 100, 117 (1941).

86. See L opez V. U nited States, 514 U .S. 549, 559 (1995).

87. 426 U .S. 833 (1976). 
opinion by J ustice R ehnquist, the Supreme Court revived state sovereignty as an independent limitation on congressional commerce power. The Court held that the Fair Labor Standards A ct, as applied to regulate the wages and hours paid by the states to their employees, exceeded congressional authority under the Commerce Clause. ${ }^{88}$ Congress simply could not, under the guise of the Commerce Clause, "displace the States' freedom to structure integral operations in areas of traditional governmental functions." ${ }^{89}$ Congressional determination of wages paid by the states to employees discharging those functions intruded upon an essential "attribute of state sovereignty." opinion, Justice Blackmun expressed his view that federal commerce power should be preserved only where an overriding federal interest could be shown, suggesting, in effect, a strict scrutiny standard of review rather than the rational basis standard generally applied where the essential attributes of state sovereignty are not directly implicated. ${ }^{91}$

Subsequently, in Hodel v. Virginia Surface M ining and Reclamation A ssociation, ${ }^{92}$ the Court refused to expand National League of Cities to limit congressional regulation of private activities traditionally within the realm of the states' police powers. Instead, it stated that the principles underlying $\mathrm{N}$ ational L eague of Cities must be confined to intrusions upon state sovereignty where state actors act as states, and not where the federal regulation applies to individuals. ${ }^{93}$ J ustice R ehnquist concurred in the Court's judgment that the Surface Mining Control and Reclamation A ct did not violate the Commerce Clause, but he disagreed with any suggestion that "the federal system exists only at the sufferance of Congress." ${ }^{94}$ Chief J ustice R ehnquist enthusiastically reaffirmed the principle that dual sovereignty inherent in the Constitution more generally imposes constitutional limits on the scope of the congressional commerce power. ${ }^{95}$

The Court reversed course in Garcia v. San A ntonio M etropolitan Transit A uthority, ${ }^{96}$ and overruled $N$ ational L eague of Cities. In his majority opinion, J ustice B lackmun, reversing his own stand in National L eague of Cities, determined that defining the states' traditional governmental functions under $\mathrm{Na}$ tional L eague of Cities was too onerous a task. He expressed frustration over what he termed a failure "to identify an organizing principle" that would properly define the limits of congressional commerce power vis á vis the states. ${ }^{97}$ In

\footnotetext{
88. See id. at 852 .

89. Id.

90. Id. at 845 .

91. See id. at 856. A ccording to J ustice Blackmun, the Court adopted "a balancing approach" that would not proscribe congressional power "where the federal interest is demonstratably greater" than state interest. Id.

92. 452 U .S. 264 (1981).

93. See id. at $286-88$.

94. Id. at 308.

95. See id. at 309-10.

96. 469 U .S. 528 (1985).

97. Id. at 539 .
} 
the majority's view, state sovereignty concerns could be better protected by the political process itself-through elected legislative representatives-than by stand-alone principles of federalism. ${ }^{98}$ The Court did not question the central theme of $\mathrm{N}$ ational $\mathrm{L}$ eague of Cities that the position of the states in our federal structure limits the scope of congressional authority under the Commerce Clause, or that essential "postulates" of federalism, behind the words of the Constitution, limit and control congressional power and protect the essentials of state sovereignty. Instead, the Court simply abdicated and assigned its judicial function to the legislative branch. The Court stated that "we have no license to employ freestanding conceptions of state sovereignty when measuring congressional authority under the Commerce Clause," ${ }^{99}$ and that state sovereign interests are protected more properly by "the effectiveness of the federal political process." 100

While the majority's opinion in G arcia hardly advanced the cause of federalism, the passionate dissent can only be described as its manifesto and as a harbinger of its resurrection. In a scathing dissent, joined by Chief J ustice B urger and J ustices Rehnquist and $\mathrm{O}^{\prime}$ Connor, J ustice Powell stated that the majority decision "substantially alters the federal system embodied in the Constitution," "101 it "effectively reduces the Tenth A mendment to meaningless rhetoric when Congress acts pursuant to the Commerce Clause," 102 and "an unelected majority of five J ustices . . . to day rejects almost 200 years of the understanding of the constitutional status of federalism." ${ }^{103}$ The dissent was particularly offended by the majority's naive understanding of the federal political process and the factual premises that have compromised that process's purported role as the guardian of state concerns. The dissent identified a number of factors, including, among others, the rise of national media and the weakening of political parties at the local level, that "have made Congress increasingly less representative of state and local interests, and more likely to be responsive to the demands of various national constituencies." ${ }^{104}$ The dissent pointed to the increase in recent years of sophisticated lobbying by special interest groups that make substantial campaign contributions to members of Congress, concluding that, contrary to the majority's view, "a 'political process' that functions in this way is unlikely to safeguard the sovereign rights of States." ${ }^{105}$ In the dissent's view, these sovereign rights of the states have been constitutionally enshrined by the Tenth A mendment, which is "an essential part of the Bill of Rights," 106 and these rights are no more protected by the political process than the rights

\footnotetext{
98. See id. at 552 .

99. Id. at 550 .

100. Id. at 552 .

101. Id. at 557 .

102. Id. at 560 .

103. Id.

104. Id. at 565 n.9.

105. Id. at 575 n. 18 .

106. See id. at 565 n.8.
} 
to free speech, representation by counsel, judicial redress of grievances, and due process of law. ${ }^{107}$ Indeed, inclusion of the Bill of R ights and its provision affirming the residual powers of the states was critical to the positive vote on ratification. ${ }^{108}$ Certainly, the dissent emphasized, members of Congress should not be permitted to serve as the arbiters of the rights retained by the states or as the sole judges of the limits of their own power under the Commerce Clause. A fter all, J ustice Powell stated, "the [s]tates' role in our system of government is a matter of constitutional law, not of legislative grace."

The dissenting Justices in G arcia focused extensively on the views of the Constitution's framers in their division of authority between the federal and state governments, including M adison's elaboration in the F ederalist N o. 45:

The powers delegated by the proposed Constitution to the Federal Government, are few and defined. Those which are to remain in the State $\mathrm{G}$ overnments are numerous and indefinite. The former will be exercised principally on external objects, as war, peace, negotiation, and foreign commerce.... The powers reserved to the several [s]tates will extend to all the objects, which, in the ordinary course of affairs, concern the lives, liberties and properties of the people; and the internal order, improvement, and prosperity of the [s]tate. 110

A dditionally, they reiterated Hamilton's views, as reflected in the Federalist No. 17, that the States "regulat[e] all those personal interests and familiar concerns to which the sensibility of individuals is more immediately awake," that people perceived the states as "the immediate and visible guardian of life and property," and that this contributed "more than any other circumstance" to the people's respect for and loyalty to the government. ${ }^{111}$ A ccording to the G arcia dissent, "by usurping functions traditionally performed by the States, federal overreaching under the Commerce Clause undermines the constitutionally mandated balance of power between the States and the [f]ederal [g]overnment, a balance designed to protect our fundamental liberties." ${ }^{112}$ The dissent noted that the constitutional debates clearly demonstrated that the power granted to Congress under the Commerce Clause only extends to commerce that the states lacked the practical capacity to regulate, a postulate implicit in its language, "[t]o regulate [c]ommerce with foreign [n]ations, and among the several [s]tates, and with the Indian [t]ribes." ${ }^{113}$ Congressional commerce power, accordingly, is exceptional, limited to the incapabilities of the states, ${ }^{114}$ and all other commerce power, indeed, "nearly the whole charge of interior regulation," ${ }^{115}$ remains with the states and the people since it is not expressly delegated to the federal government.

107. Seeid.

108. Id. at 568 .

109. Id. at 567.

110. Id. at 570-71 (quoting THE FEDERA LIST N O. 45 (J ames M adison) (J. Cooke ed. 1961)).

111. Id. at 571 (quoting THE FEDERA LIST N O. 17 (A lexander H amilton) (J. Cooke ed. 1961)).

112. Id. at 572 .

113. Id. at 572 (quoting U S. CONST. art. I, § 8, cl. 3).

114. See id. at 572 .

115. Id. at 573 (quoting Lane County v. O regon, 74 U .S. (7 Wall.) 71 (1869)). 
In concluding his Garcia dissent, Justice Powell, in search of the elusive "organizing principle," argued for application of a balancing test that would allow federal intrusion only where the federal interest is demonstrably greater than the interests of the states. ${ }^{116}$ In a separate dissent, J ustice 0 'C onnor expressed her view that the balancing test should weigh state autonomy as a factor in determining the limits of congressional Commerce Clause power to regulate states as states. ${ }^{117}$ In his own brief dissent, J ustice R ehnquist refused to commit to the balancing tests proposed by J ustices Powell and $\mathrm{O}$ 'Connor, noting that National L eague of Cities recognized that Congress had no commerce power at all to infringe on fundamental aspects of state sovereignty essential to the states' separate and independent existence. ${ }^{118} \mathrm{He}$ simply concluded by expressing confidence that the principles underlying National L eague of Cities would "in time again command the support of a majority of this Court." 119

J ustice R ehnquist did not get the first opportunity to undo the damage to federalism he believed was done by the majority in $\mathrm{G}$ arcia. This fell to J ustice 0 'Connor, who, in two significant opinions, rejected the notion that the political process was a sufficient safeguard for state sovereignty. In the first, G regory v. A shcroft, ${ }^{120}$ she began by stating, "A s every schoolchild learns, our Constitution establishes a system of dual sovereignty between the [s]tates and the [f]ederal [g]overnment." ${ }^{121}$ She outlined the numerous advantages of "a federalist structure of joint sovereigns." ${ }^{122}$ She identified as the most important of these its ability to prevent the accumulation of excessive power by either, accomplishing the "double security" described by Madison in the Federalist No. 51 that reduces the risk of tyranny and abuse. ${ }^{123}$ In a decision the dissenters claimed directly contravened $\mathrm{G}$ arcia, ${ }^{124}$ the majority held that congressional commerce power as exercised in its A ge Discrimination in Employment Act could not compel the age qualifications of $M$ issouri's state judges. ${ }^{125}$

Similarly, in N ew Y ork v. U nited States, ${ }^{126}$ J ustice $\mathrm{O}^{\prime} \mathrm{C}$ onnor, again writing for the majority, struck down provisions of Congress's Low-L evel R adioactive Waste Policy A ct, which compelled the states to either "take title" to waste generated within their borders or to regulate pursuant to congressional instructions. In this decision, Justice 0 'Connor noted two related approaches to setting the limits of state and federal power under the Constitution. The first is whether Congress has acted pursuant to a power delegated to it by the Consti-

116. See id. at 562 (Powell, J ., dissenting).

117. Seeid. at 588 .

118. See id. at 579-80.

119. Id. at 580 .

120. 501 U.S. 452 (1991).

121. Id. at 457.

122. Id. at 458.

123. See id. at $458-59$.

124. See id. at 477 (W hite, J., dissenting in part).

125. See id. at 473.

126. 505 U .S. 144 (1992). See generally Thomas W. K elty, Federalism: While the Stewards Slept... N ew Y ork v. U nited States, 29 U R B. L A W. 529 (1997). 
tution, the second, whether Congress has acted in a way that usurps the powers reserved to the states by the Tenth $A$ mendment. ${ }^{127}$ Both inquiries, Justice 0 'Connor stated, are but "mirror images of each other," gated to Congress in the Constitution, the Tenth A mendment disclaims it, and if power is an attribute of state sovereignty reserved by the Tenth A mendment, it is not a power delegated to Congress. In this case, the Court held that the Constitution simply did not confer upon Congress the ability to compel the states to regulate in a particular field, to require the states to govern according to congressional instructions, or to otherwise commandeer the states to implement federal regulatory policies. ${ }^{129}$ In doing so, however, the Court stated that while Congress cannot regulate the states' regulation of interstate commerce, it can regulate directly and thus preempt the states by virtue of the Supremacy Clause. $^{130}$ A gain, the Court touted federalism without fully linking it to the Commerce Clause.

The principles addressed by Justice 0 'Connor writing for the majority in Gregory and N ew Y ork were again reaffirmed by the Supreme Court in the summer of 1997, in Printz v. U nited States. ${ }^{131}$ In an opinion written by J ustice Scalia, the Court, asserting stand-alone postulates of federalism, invalidated provisions of the Brady $\mathrm{H}$ andgun $\mathrm{V}$ iolence Prevention $\mathrm{A}$ ct that required state law enforcement officers to conduct background checks on handgun purchasers. A ccording to the majority, the federal government, under the purported exercise of Commerce Clause powers and the supplemental Necessary and Proper Clause, "may not compel the States to enact or administer a federal regulatory program." 132 M oreover, because the legislation seeks "to direct the functioning of the state executive, and hence to compromise the structural framework of dual sovereignty," it would be inappropriate to apply a balancing test that would weigh asserted federal interests against those of the states. ${ }^{133}$ This may explain why J ustice R ehnquist, in his cryptic $G$ arcia dissent, refused to commit to any balancing test. A ccording to Justice Scalia, "it is the very principle of separate state sovereignty that such a law offends, and no comparative assessment of the various interests can overcome that fundamental defect." ${ }^{134}$ Further elaborating on this principle, J ustice Scalia observed that the courts have traditionally invalidated legislation that has deviated from the form of government the Constitution established as its primary concern. ${ }^{135}$ Q uoting

127. See 505 U.S. at 155.

128. Id. at 156.

129. See id. at $175-77$.

130. See id. at 178-79.

131. 117 S. Ct. 2365 (1997).

132. Id. at 2380 (quoting N ew Y ork v. U nited States, 505 U .S. 144, 188 (1992)).

133. Id. at 2383.

134. Id. (citing Plaut v. Spendthrift Farm Inc., 514 U .S. 211, 239-240 (1995) (holding legislated invalidation of final judgments to be categorically unconstitutional); B owsher v. Synar, 478 U .S. 714, 736 (1986) (declining to subject principle of separation of powers to a balancing test); I N S v. Chadha, 462 U.S. 919, 944-46 (1983) (same)).

135. Id. at 2383. 
language from Justice $\mathrm{O}$ 'Connor's majority opinion in New York v. U nited States, he stated that "the Constitution protects us from our own best intentions: It divides power among sovereigns and among branches of government precisely so that we may resist the temptation to concentrate power in one location as an expedient solution to the crisis of the day." ${ }^{136}$ Thus, the Court effectively reversed Justice Blackmun's majority opinion in $\mathrm{G}$ arcia that "freestanding conceptions of state sovereignty cannot be employed to limit [c]ongressional authority under the Commerce Clause." A ccording to Printz, they can and they do.

Two years before the Printz case, Chief J ustice R ehnquist's turn to speak finally came in L opez v. United States, ${ }^{137}$ in which he fulfilled his own G arcia prophecy. Now Chief J ustice R ehnquist, joined by Justices O 'Connor, Scalia, Kennedy, and Thomas, rejected on Commerce Clause grounds the G un-Free School Zones A ct, which prohibited possession of firearms in a school zone. ${ }^{138}$ $\mathrm{H}$ e began by emphasizing that dual sovereignty defines the outer limits of congressional commerce power, and congressional power cannot be used to obliterate the distinction between what is national and what is local, so as to create a completely centralized government. ${ }^{139}$ Congress only has commerce power to regulate the use of channels of interstate commerce and their instrumentalities, persons, and property moving in interstate commerce, and activities having a substantial relation to interstate commerce. ${ }^{140}$ The majority held that the criminal statute at issue did not fall within any of these three categories. ${ }^{141}$ In fact, according to Chief J ustice R ehnquist, the challenged law had nothing to do with "commerce." ${ }^{142}$ The majority dismissed the government's argument that the cost of crime and its effect on national productivity provided the requisite commercial nexus, for if accepted, Congress would be enabled to regulate anything. ${ }^{143}$ Furthermore, the Constitution does not grant Congress a plenary police power. ${ }^{144}$ Thus, unless it can be demonstrated that the regulated activity has a substantial effect on interstate commerce, ${ }^{145}$ the law cannot be sustained to regulate either state or private activities. ${ }^{146}$

In Chief J ustice R ehnquist's view, the court's elusive "organizing principle" did not involve any balancing of the relative interests of Congress and those of the states. Instead, it must be built on the core postulate that the people granted Congress power over interstate commerce limited to the regulation of activities that have a substantial economic effect on interstate commerce, as op-

\footnotetext{
136. Id. (quoting N ew Y ork v. U nited States, 505 U .S. at 188).

137. 514 U .S. 549 (1995).

138. See id. at 568 .

139. See id. at 557

140. See id. at 558-559.

141. See id. at 559-61.

142. See id. at 561 .

143. See id. at 564 .

144. Seeid. at 566

145. See id. at 559 .

146. Seeid. at 558-59.
} 
posed to activities having indirect or insubstantial effects. ${ }^{147} \mathrm{He}$ acknowledged the Court's prior holdings limiting the states' retained commerce powers to regulation that did not discriminate against interstate commerce. ${ }^{148}$ Thus, with the exception of congressional power to regulate "economic activity [that] substantially affects interstate commerce," ${ }^{149}$ the states, under our federalist structure, retain all other commerce powers together with this plenary police powers, unless their exercise would be discriminatory or excessively burdensome on interstate commerce. ${ }^{150}$ Chief J ustice R ehnquist conceded the imprecision of his formulation and the necessary elasticity of the limits on congressional commerce power. ${ }^{151}$ N evertheless, he contended, federalism demands "a distinction between what is truly national and what is truly local," 152 and does not permit conversion of "congressional authority under the Commerce Clause to a general police power of the sort retained by the [s]tates." ${ }^{153}$

In his separate Lopez concurrence, Justice Kennedy, joined by Justice 0 'Connor, confirmed the significance of the various structural elements of the Constitution, including federalism, separation of powers, checks and balances, and judicial review. ${ }^{154}$ A mong these elements, federalism was "the unique contribution of the Framers to political science." ${ }^{155}$ Adhering to Madison's "double security" principle, Justice K ennedy warned that to allow Congress to take over areas of traditional state concern would blur the lines "between the spheres of federal and state authority" and render political responsibility "illusory." 156 J ustice K ennedy reasoned that just as the Court has limited the power of the states under the dormant Commerce Clause, it must also determine the limits of congressional power under the Commerce Clause where its exercise would intrude upon an area of traditional state concern. ${ }^{157}$ A Ithough the challenged statute did not commandeer or direct the states to regulate in an instructed way, as in New York v. U nited States, the congressional intrusion upon state powers was nevertheless a fatal constitutional flaw.

In his own concurring opinion, J ustice Thomas expressed continued frustration with the court's failure to develop a more precise "organizing principle" for the delineation of congressional commerce power. He urged reconsideration by the Court of its substantial effects test and the construction of a more coherent test to divide commerce power between Congress and the states. In his view, the substantial effects on interstate commerce standard was far too broad as a result of Court's "wrong turn" in the 1930s from a century and a half

\author{
147. See id. \\ 148. Seeid. \\ 149. Id. at 560 (emphasis added). \\ 150. Seeid. at 558-59. \\ 151. See id. at 566-67. \\ 152. Id. at 567-68. \\ 153. Id. at 567 . \\ 154. See id. at 575 \\ 155. Id. \\ 156. Id. at 577 . \\ 157. See id. at 580 .
}


of precedent. ${ }^{158}$ The Commerce Clause, after all, was never intended to grant police powers to Congress, but rather to regulate directly interstate economic activities.

\section{B. Constitutional Limits on State Commerce Power}

A nalysis of the limits on congressional commerce power, as suggested by J ustice Kennedy in his L opez concurrence, necessarily requires consideration of limits imposed on the commerce powers of the states. A s J ustice 0 'C onnor explained in N ew Y ork v. U nited States, the power constitutionally delegated to Congress is not reserved to the states, and the powers reserved to the states have not been delegated to Congress by the Constitution. To determine whether her "mirror images" metaphor is functional, one must compare both images. U nder our federalist structure, the states possess all powers not delegated to the federal government by the Constitution, as affirmed by the Tenth A mendment's inclusion in the Bill of Rights. Consequently, the states have power over all subject areas that do not substantially affect interstate commerce. M oreover, since the country's beginnings, the states possessed plenary police powers, which include the power to regulate commerce in order to protect the health, morals, and well-being of their citizens. ${ }^{159}$ The Supreme Court has held that the states possess power, derivative of their plenary police powers, to regulate interstate commerce, at least in areas where Congress has remained silent (or has exceeded its own power under the Commerce Clause). ${ }^{160}$

In prescribing limits on this concurrent power of the states, the Court has held that the so-called "dormant" Commerce Clause, by negative implication, generally forbids state legislation that would discriminate against interstate commerce or would otherwise impose an excessive burden on interstate commerce. ${ }^{161}$ The Court has repeatedly declared that the guiding principle behind the dormant Commerce Clause jurisprudence is the prevention of "economic protectionism" by the individual states. ${ }^{162}$ Thus, whenever state legislation in pursuit of police power objectives is found discriminatory, the Court has applied a "strict scrutiny" standard of review. In other words, the Court will strictly scrutinize the purported objectives of the state police power exercised and the availability of less restrictive alternatives. ${ }^{163}$ In cases where the state's legislation is even-handed or nondiscriminatory in its application to interstate commerce, the Court has applied an ad hoc balancing test to determine whether the legislation imposes an excessive burden on interstate commerce. In determining excessiveness, the Court weighs the regulatory interests of the

158. Id. at 599.

159. See G ibbons v. O gden, 22 U.S. ( 9 W heat.) 1, 203 (1824).

160. See Cooley v. B oard of W ardens, 53 U.S. ( 12 H oward) 299, 320 (1851).

161. See Pike v. B ruce Church, Inc., 397 U .S. 137, 142 (1970).

162. See, e.g., West L ynn Creamery, Inc v. Healy, 512 U .S. 186, 192-93 (1994); N ew Energy Co. v. L imbach, 486 U .S. 269, 273-74 (1988); B acchus I mports, L td. v. D ias, 468 U .S. 263, 270 (1984).

163. See, e.g., Chemical W aste M gt., Inc. v. H unt, 504 U.S. 334, 342-43 (1992); M aine v. Taylor, 477 U.S. 131, 138 (1986); H ughes v. O klahoma, 441 U.S. 322, 336 (1979). 
state under its police powers against the legislation's actual effect on the flow of interstate commerce. In applying this balancing test, the Court has assigned the greatest weight to state regulatory interests that fall within traditional police power concerns, including, among others, the prevention of fraud and unfair business practices.

N owhere has this been more evident than where states have used their police powers to protect their citizens against securities fraud. The Supreme Court consistently has rejected Commerce Clause challenges to state blue sky laws since shortly after they were first enacted. In the three Blue Sky Cases ${ }^{164}$ in 1917, constitutional assaults were leveled at the securities laws then in effect in the states of O hio, South Dakota, and M ichigan. In the first of these cases, $\mathrm{H}$ all v. G eiger-J ones $\mathrm{C} 0 .{ }^{165}$ the challengers were an $\mathrm{O}$ hio corporation acting as a broker-dealer in numerous states, two individual traders, and a W est V irginia corporation with its principal place of business in $\mathrm{O}$ hio. They alleged, among other theories, that the O hio statute, which gave the state commissioner the power to revoke securities licenses of dealers and issuers engaging or about to engage in fraudulent transactions, imposed an excessive burden on interstate commerce. In framing the issue as "an asserted conflict between national power and state power," ${ }^{166}$ the Supreme Court found that the statute was a valid exercise of the state's police power, describing this power as "the least limitable of the exercises of government" 167 and reaffirming "the principle of the power of the states to prevent frauds and impositions." ${ }^{168}$ A fter weighing the state's regulatory interests, it then assessed the state law's effects on interstate commerce. While the law required filing of information by companies issuing securities in other states, the law's primary impact was realized only when disposition of securities was to be made within the state. ${ }^{169}$ The Court held that the $\mathrm{O}$ hio blue sky law affected interstate commerce only incidentally and thus did not constitute an impermissible burden on interstate commerce. ${ }^{170}$ The Court reached similar conclusions in the other two Blue Sky Cases, Caldwell v. Sioux Falls Stock Y ards C 0., ${ }^{171}$ and M errick V. N.W. Halsey \& C $0 .{ }^{172}$ In M errick, the Court noted that the $M$ ichigan blue sky law "burdens honest business, it is true, but burdens it only that under its forms dishonest business may not be done," and that while expense and inconvenience may be caused, this does not arrest the power of the states, for "it costs something to be governed." ${ }^{173}$ A Ithough these cases preceded the enactment of the federal securities laws, they

164. M errick v. N.W. Halsey \& Co., 242 U.S. 568 (1917); Caldwell v. Sioux Falls Stock Y ards Co., 242 U .S. 559 (1917); H all v. G eiger-J ones Co., 242 U .S. 539 (1917).

165. 242 U .S. 539 (1917).

166. Id. at 548 .

167. Id.

168. Id. at 552 .

169. See id. at 557-58.

170. See id. at 559 .

171. 242 U .S. 559 (1917).

172. 242 U .S. 568 (1917).

173. Id. at 587 . 
have been consistently applied to reaffirm state securities laws as "a well[-]recognized exercise of the police power of the States." ${ }^{174}$

M ore recently, the Supreme Court, in CTS Corp. v. Dynamics Corp. of A merica, ${ }^{175}$ was presented with a Commerce Clause challenge to an Indiana law protecting its domestic corporations and their shareholders in the context of hostile corporate stock tender offers. In upholding the Indiana statute under the dormant Commerce Clause, the Court began by noting that "the principal objects of dormant Commerce Clause scrutiny are statutes that discriminate against interstate commerce." ${ }^{176}$ The Indiana law, the Court observed, had the same effects on securities offerors in-state and out-of-state, and thus was nondiscriminatory. ${ }^{177}$ The Court then focused extensively on the traditional role of the states in the field of corporate organization, securities creation, and corporate governance. It underscored the significance for Commerce Clause analysis of the truism that the existence and attributes of the corporate entity are products of state law and that these laws necessarily affect interstate commerce. ${ }^{178}$ Concluding that the Indiana statute did not offend the Commerce Clause, despite its effects on interstate commerce, the Court observed:

Large corporations that are listed on national exchanges, or even regional exchanges, will have shareholders in many States and shares that are traded frequently. The markets that facilitate this national and international participation in ownership of corporations are essential for providing capital not only for new enterprises but also for established companies that need to expand their businesses. This beneficial free market system depends at its core upon the fact that a corporation ... is organized under, and governed by, the law of a single jurisdiction, traditionally the corporate law of the $[s]$ tate of its incorporation. . . . 179

It is thus an accepted part of the business landscape in this country for states to create corporations, to prescribe their powers, and to define the rights that are acquired by purchasing their shares. A [s]tate has an interest in promoting stable relationships among parties involved in the corporations it charters, as well as in ensuring that investors in such corporations have an effective voice in corporate affairs. . . 180

We have rejected the "notion that the Commerce Clause protects the particular structure or methods of operation in a ... market." [citation omitted] The very commodity that is traded in the securities market is one whose characteristics are defined by state law. . . .181

To the limited extent that the A ct affects interstate commerce, this is justified by the [s]tate's interests in defining the attributes of shares in its corporations and in protecting shareholders. 182

In his concurring opinion, J ustice Scalia stated, "as long as a State's corporation law ... does not discriminate against out-of-state interests, it should sur-

174. Travelers Health A ss'n v. V irginia, 339 U .S. 643, 653 (1950) (D ouglas, J ., concurring).

175. 481 U .S. 69 (1987).

176. Id. at 87.

177. Seeid.

178. Seeid. at 89-90.

179. Id. at 90 (emphasis added).

180. Id. at 91.

181. Id. at 93-94.

182. Id. at 94. 
vive this Court's scrutiny under the Commerce Clause, whether it promotes shareholder welfare or industrial stagnation." 183 In other words, regardless of whether one agrees with the benefits or the burdens federalism may produce, it mandates strict protection of state power. J ustice Scalia noted further that the states have "sacrosanct authority," both in structuring domestic corporations and in their enactment of blue sky laws, including investor remedies, to protect buyers and sellers of those corporations' securities. ${ }^{184}$ In CTS Corp., the Court understood that it would be difficult, if not impossible, to slice away the securities aspect of corporate law when the securities themselves are the corporate pieces that form the whole. A ccordingly, prevention of fraud and making remedies available to defrauded securities investors are inherent in state regulation of corporations and among the most significant of the states' traditional police power concerns.

The dormant Commerce Clause cases illustrate the breadth of commerce and police powers retained by the states under the Constitution. They offer useful guidance in determining constitutionally protected local domains for state governance frequently referred to as either essential attributes of state sovereignty or as areas of traditional state concern. Because congressional commerce power is exceptional in nature, geared to the incorporations of the states and extending only to economic activities that substantially affect interstate commerce, the residual powers of the states should be broadly construed to delineate congressional authority under the Commerce Clause, the exercise of which would otherwise preempt the states from the exercise of their own plenary powers. J ustice R ehnquist implicitly adopted this approach in L opez, when he simply barred Congress from intruding into matters of local concern, refusing even to balance federal interests against state interests. In L opez, state power was found sacrosanct. However, as J ustice Thomas stated in his L opez concurrence, a more coherent test for determining the limits of congressional commerce power is critically necessary. This lack of coherence has resulted from a certain "mushiness" in defining the residuum of state power that was delegated to Congress by the Commerce Clause. A Ithough L opez initiated a return to "hardened" stand-alone postulates of federalism that pretermit Congress from defining its own commerce power, these postulates have not risen to the level of the long-sought after "organizing principle" and have not yet produced a sufficiently coherent test against which congressional use of its commerce power might be measured. The coherency objective could be advanced significantly by a closer examination of the functional relationship between "active" and "dormant" Commerce Clause jurisprudence.

183. Id. at 95-96.

184. Id. at 96 (Scalia, J., concurring in part and concurring in the judgment); see also Goodyear A tomic Corp. v. M iller, 486 U .S. 174 (1988). 
IV

The A protopriate A llocation of Regulatory Power OVer INTERSTA TE COMMERCE

\section{A. Symmetrical A nalysis of the Commerce Clause}

The essential postulates of federalism, as amplified by the Supreme Court in L opez and other active Commerce Clause cases, as well as in CTS Corp. and other dormant Commerce Clause cases, underscore the necessity for strengthening the linkage between the ambits of both federal and state power under the Commerce Clause. J ustice K ennedy suggested this approach in his L opez concurrence, as J ustice $\mathrm{O}$ 'C onnor had done in her $\mathrm{N}$ ew $\mathrm{Y}$ ork v. U nited States discussion of the "mirror images" of powers delegated and powers retained. The vitality of federalism largely depends on the symmetrical interrelationship between active and dormant Commerce Clause doctrines. The failure to develop this symmetry has generated an often confused and inconsistent jurisprudence.

Traditionally, the limits of state commerce power established by dormant Commerce Clause interpretation have been applied only in the context of congressional silence, or where Congress has not acted validly under its Commerce Clause power in a manner that would invoke the Supremacy Clause to preempt the states from exercising their concurrent power. H owever, the relevance of dormant Commerce Clause principles lies within their implicit recognition of the role of the states in our federalist structure. The states, not the federal government, hold the residuum of power under the Constitution. Thus, it is more than plausible that the reach of the states' commerce power should properly define the limits of federal commerce power, and not the converse. This would provide the missing link between the federalism guaranteed by our Constitution and the exercise of commerce power granted to the federal legislature. ${ }^{185}$ In other words, the Constitution did not grant plenary police powers to the federal government. Instead, these powers were reserved to the states. Thus, any usurpation of these powers by the federal government should be as strictly construed as state legislation that discriminates against interstate commerce in favor of its own. Because the states' plenary police powers necessarily and approximately affect commerce, subject to dormant Commerce Clause prohibitions against discrimination and excessive burdens upon interstate commerce, the states' power exercised within those limits should generally foreclose usurpation by Congress under the Commerce Clause. If the states have observed these limits, they have not invaded but, rather, have actually defined the limits of congressional power under the Commerce Clause. Congressional power is thus unfettered by state power over commerce since the state's

185. See Paul Wolfson, Preemption and Federalism: The M issing L ink, 16 HA STINGS CONST. L.Q . 69 (1988). A ccording to Professor W olfson, "the courts must restore the link between preemption and federalism" to avoid further damage to the federal system. Id. at 114. 
valid exercise of its power does not discriminate or excessively burden the interstate commerce that Congress was authorized to regulate.

Consequently, the essential postulates of federalism, indeed, the very structural assumptions giving rise to dual sovereignty, are fully served by the balance of state and federal power achieved. Federalist principles would be firmly linked to congressional power under the Commerce Clause and the Supremacy Clause that protects its exercise. State sovereignty would no longer be victimized as Native A mericans were by continual federal encroachment. The Commerce Clause would no longer be the vehicle for carving away state power by congressional whim. Under this approach, due respect would be accorded the states as holders of the residual power instead of the reverse. A state's proper exercise of its concurrent commerce power derivative of its police powers or otherwise, absent discrimination or imposition of an excessive burden, would establish a presumption that conflicting federal legislation exceeds the limits of Congress's Commerce Clause power. U nder these circumstances, Congress's power under the Commerce Clause would be insufficient to override the states, because that power was simply never delegated by the people to the federal legislative branch. This presumption could be overcome only through application of a strict scrutiny standard of review, similar to that applied to discriminatory state legislation in the dormant Commerce Clause cases. A ccordingly, the exercise of federal commerce power would be authorized only where it can be demonstrated that Congress, in regulating activities shown to have substantial economic effects on interstate commerce, had a compelling federal interest that could not be achieved by less restrictive means. The battlefield for the federalstate conflict is thus squarely placed in the Commerce Clause and not in the Supremacy Clause arena where the states can never be victorious.

\section{B. The Constitutionality of Congressional Preemption of State Securities Fraud $\mathrm{R}$ emedies}

U nder the proposed uniform standards legislation, as previously described, Congress in the exercise of purported Commerce Clause power, would preempt statutory and common law remedies adopted by the states, either through their respective constitutions, their legislation, or judicial development. $R$ ather than prescribing the states' regulatory course as forbidden in Printz, Congress would simply proscribe the state's regulatory course by vetoing either a securities regulatory scheme or independently developed rules of law protecting the states' citizens against fraudulent business practices. In analyzing the constitutionality of the proposed legislation, two approaches should be considered. The first approach, relying on traditional Commerce Clause jurisprudence, as amplified by the recent Supreme Court opinions previously discussed, would focus on the express limiting language of the Commerce Clause itself as the primary restraint on congressional power. In other words, the people's delegation of power to Congress was limited to the regulation of activities that have substantial economic effects on interstate commerce. The second approach, 
relying on a symmetrical analysis of the respective commerce powers of both federal and state sovereignties, would focus on the reserved power of the states as the primary restraint on congressional power. U nder either approach, the proposed uniform standards legislation would fail as ultra vires under the Constitution.

U nder the traditional approach, the essential query is whether the proposed legislation seeks to regulate activities having substantial economic effects on interstate commerce. If it cannot be shown, through congressional findings or otherwise, that Congress had a rational basis for concluding that the regulated activities had the requisite commercial impact on interstate commerce, the legislation would be beyond the power of Congress, and, accordingly, an unconstitutional usurpation of the powers retained by the people and their respective states. The proposed uniform standards legislation does not purport to regulate the interstate distribution or disposition of securities. Instead, the legislation seeks to regulate state-law based litigation by eliminating a wide array of state law claims and remedies. A ccording to its proponents, the legislation is designed to create an exclusively federal system of securities litigation for nationally traded companies, a system in which only federal remedies could be asserted in federal courts and in which no federal or state remedies could be asserted in state courts. Thus, the activities Congress seeks to regulate are those of state legislatures in their enactment of statutory private civil remedies for fraud and breach of fiduciary duty, of state judiciaries in their development of similar common law remedies, and of private citizens seeking to recover their investment losses through assertion of those statutory and common law remedies. These fraud-related remedies granted by the states and asserted by investors are by their nature activated after the fact of the commercial transactions giving rise to their assertion. While these remedies may have incidental regulatory effects, they do not regulate commerce but, rather, accomplish the entirely separate function of compensating victims of fraud. ${ }^{186}$ These remedies involve remedial activities in judicial forums and not commercial activities in the eco-

186. J ustice Blackmun reiterated this distinction in Cipollone v. Ligget Group, Inc., 505 U .S. 504 (1992). A ccording to J ustice B lackmun, "the level of choice that a defendant retains in shaping its own behavior distinguishes the indirect regulatory effect of the common law from positive enactments." Id. at 536 (Blackmun, J., concurring in part). Furthermore, "tort law has an entirely separate functioncompensating victims- that sets it apart from direct forms of regulation." Id. at 537 (Blackmun, J., concurring in part). He observed, "It has declined ... to find the regulatory effects of state tort law direct or substantial enough to warrant pre-emption." Id. (B lackmun, J., concurring in part); see, e.g., English v. General Elec. Co., 496 U.S. 72 (1990); Goodyear A tomic Corp. v. M iller, 486 U.S. 174 (1988); Silkwood v. K err-M cG ee Corp., 464 U .S. 238 (1984). In each of these cases, J ustice Blackmun thought that despite the potential consequence of defendants altering their future behavior, the incidental regulatory effects of private damages awards were not "direct or substantial enough to warrant pre-emption." Cipollone, 505 U.S. at 537-38 (Blackmun, J., concurring in part). Moreover, the Supreme Court has recognized that a person's right of access to the courts is an important aspect of the First A mendment's right to petition the government for redress of grievances. See B ill J ohnson's Restaurants, Inc. v. N LR B, 461 U .S. 731, 741 (1983). The Court noted “in recognition of the States' compelling interest in maintenance of domestic peace," it had previously refused in San Diego Building Trades C ouncil v. Garmon, 359 U .S. 236 (1959), to preempt the states "from providing a civil remedy for conduct touching interests 'deeply rooted in local feeling and responsibility.'" Id. 
nomic marketplace. The outcome of their pursuit may implicate future commercial choices, as do most judicial pronouncements, but judicial results can hardly be described as commercial. If this were otherwise, Congress could exploit its Commerce Clause power to regulate not only the people's access to their local courts, but also the entire sphere of state court jurisdiction and procedures. Clearly, the legislative, judicial, and individual activities sought to be controlled by the pending legislation are not in any sense "commerce" and do not have a direct or substantial effect on interstate commerce. A ccordingly, these activities cannot be regulated by Congress under the Commerce Clause. Under this traditional approach, Congress would simply have no power to regulate these remedial activities, and, consequently, could not invoke the supremacy clause to protect its ultra vires legislation.

The second approach, by linking active and dormant Commerce Clause jurisprudence to the essential postulates of federalism, focuses on the extent of power retained by the people and their respective states. In other words, the retained power validly exercised by the states necessarily restricts if not forbids its exercise by Congress under the Commerce Clause. A s grantors of all political power, the people delegated limited powers to a federal government while retaining and further developing their own state sovereignties. Thus, the people, by creating a federal government while preserving the governments of their respective states, established the dual federal and state sovereignties that are the essence of A merican federalism. This historical duality, preserved and protected by the Constitution itself and its inherent structural assumptions, necessarily envisaged not only a federal legal system, but also numerous sets of nonuniform states laws, including private remedies, whether statutory or common law, to be asserted and enforced in numerous and distinct state judicial systems. More particularly, the provision of the remedies to those victimized by fraud and breach of fiduciary duty in connection with securities investments has been historically recognized as falling within the sacrosanct authority of the states to regulate areas of traditionally local concern.

However, the states' power in these areas, as discussed, is limited by the Commerce Clause as judicially interpreted in a long line of dormant Commerce Clause decisions. The states' power cannot be exercised in a manner that would result in either discrimination against interstate commerce or in the imposition of an excessive burden on interstate commerce. The state remedies slated for elimination by the proposed federal legislation clearly are not discriminatory, for they apply with equal force to both residents and non-residents of the providing states and to both domestic and foreign corporations. M oreover, these remedies, as previously explained, do not involve "commerce" but, rather, the assertion of after-the-fact judicial remedies for "broken" commercial transactions previously consummated. In determining the "excessiveness" of these remedies' burden on interstate commerce, obviously both burden and commerce must be the predicates for further analysis. In other words, there can be no burden where there is no commerce, and without that burden there can be no excessiveness. W ere we to assume arguendo some burden on commerce, 
the courts generally have applied an ad hoc balancing test pursuant to which the state's regulatory interests are weighed against the actual effects of the subject state laws on the flow of interstate commerce. A s seen, the courts have accorded the greatest weight to state regulatory interests, like those at issue, that fall within traditional state police power concerns. In the application of the ad hoc balancing test to the states' investor protection remedies, the states' "sacrosanct authority" to protect investors against securities fraud and to prevent their own citizens from committing that fraud, particularly their own locally created corporate issuers, would be heavily weighed against the remedy's indirect, incidental and after-the-fact impact, if any, on the flow of interstate commerce. U nquestionably, the states' investor protection remedies continue to survive Commerce Clause scrutiny and, being constitutionally reserved, can not be stripped away by an aggressive Congress. O nce these dormant Commerce Clause issues are resolved in favor of the states, overriding state power would be presumed.

While Congress has continuing authority to regulate interstate commerce in securities, it can not regulate post-commerce securities fraud remedies constitutionally provided by the states. The states' constitutional exercise of their powers to provide these remedies presumptively forecloses usurpation of these powers by Congress acting under assumed Commerce Clause authority. The resultant presumption could be overcome only if, under strict scrutiny, it could be clearly demonstrated that Congress, in regulating activities shown to have substantial economic effects on interstate commerce, has a compelling federal interest that could not be achieved by less restrictive means. U nder this final inquiry, requiring strict scrutiny of both the federal interests and the means by which they are to be advanced, it is inconceivable that creating a national system of securities litigation in order to achieve uniformity for a protected class of defendants would be found sufficiently compelling to override the role of the states in the protection of their investors and in the prevention of securities fraud. A nd it would be equally inconceivable that less drastically intrusive means could not be employed.

\section{CONCLUSION}

This article has described recent congressional efforts to weaken federal remedies for securities fraud, to eliminate before-the-fact review of securities offerings by state administrative agencies and to preempt fraud and breach of fiduciary duty remedies provided by state law. The first two objectives already have been achieved and the last objective now enjoys substantial bi-partisan political support. However, essential postulates of federalism, as recently reinvigorated by the Supreme Court, when linked to active and dormant Commerce Clause jurisprudence, are likely to present a difficult, if not insurmountable, barrier to legislation that would preempt investor remedies under state laws. A s Chief J ustice M arshall once stated, "no political dreamer was ever 
wild enough to think of breaking down the lines which separate the [s]tates, and of compounding the A merican people into one common mass." ${ }^{187}$ This was true, perhaps, when those political dreamers were not financed by the vast wealth of our present-day lobbying empires. Today, political dreamers are enjoying considerable success in making their dreams come true. U nless the courts vigorously apply constitutional restraints on congressional commerce power, it will be our A merican federalism that becomes a dream.

187. M cCulloch v. M aryland, 17 U .S. (4 Wheat.) 316, 403 (1819). 